\title{
Improving the physical, mechanical and energetic properties of Quercus spp. wood pellets by adding pine sawdust
}

\author{
Víctor Daniel Núñez-Retana ${ }^{1}$, Rigoberto Rosales-Serna ${ }^{2}$, José Ángel Prieto-Ruíz ${ }^{3}$, Christian Wehenkel ${ }^{4}$, Artemio \\ Carrillo-Parra ${ }^{\text {Corresp. } 4}$ \\ ${ }^{1}$ Maestría Institucional en Ciencias Agropecuarias y Forestales, Universidad Juárez del Estado de Durango, Durango, Durango, Mexico \\ 2 Campus Valle del Guadiana, Instituto Nacional de Investigaciones Forestales, Agrícolas y Pecuarias, Durango, Durango, México \\ 3 Facultad de Ciencias Forestales, Universidad Juárez del Estado de Durango, Durango, Durango, Mexico \\ 4 Instituto de Silvicultura e Industria de la Madera, Universidad Juárez del Estado de Durango, Durango, Durango, Mexico \\ Corresponding Author: Artemio Carrillo-Parra \\ Email address: acarrilloparra@ujed.mx
}

Background. Biomass usage for energy purposes has emerged in response to global energy demands and environmental problems. The large amounts of by-products generated during logging are rarely utilized. In addition, some species (e.g. Quercus spp.) are considered less valuable and are left in the cutting areas. Production of pellets from this alternative source of biomass may be possible for power generation. Although the pellets may be of lower quality than other types of wood pellets, because of their physical and technological properties, the addition of different raw materials may improve the characteristics of the oak pellets.

Methods. Sawdust from the oak species Quercus sideroxyla, Q. rugosa, Q. laeta and Q. conzattii was mixed with sawdust from the pine Pinus durangensis in different ratios of oak to pine $(100: 0,80: 20$, $60: 40,40: 60$ and 20:80). Physical and mechanical properties of the pellets were determined, and calorific value tests were carried out. For each variable, Kolmogorov-Smirnov normality and Kruskal-Wallis tests were performed and Pearson's correlation coefficients were determined (considering a significance level of $p<0.05)$.

Results. The moisture content and fixed carbon content differed significantly $(p<0.05)$ between the groups of pellets (i.e. pellets made with different sawdust mixtures). The moisture content of all pellets was less than $10 \%$. However, volatile matter and ash content did not differ significantly between groups $(p \geq 0.05)$. The ash content was less than $0.7 \%$ in all mixtures. The addition of $P$. durangensis sawdust to the mixtures improved the bulk density of the pellets by $18 \%$. Significant differences $(p<0.05)$ in particle density were observed between species, mixtures and for the species $\times$ mixture interaction. The particle density was highest in the 80:20 and 60:40 mixtures, with values ranging from 1,245 to $1,349 \mathrm{~kg}$ $\mathrm{m}^{-3}$. Bulk density and particle density of the pellets were positively correlated with the amount of $P$. durangensis sawdust included. The mechanical hardness and impact resistance index (IRI) differed significantly $(p<0.05)$ between groups. The addition of pine sawdust decreased the mechanical hardness of the pellets, up to $24 \%$. The IRI was highest (138) in the Q. sideroxyla pellets (100:0). The mechanical hardness and IRI of the pellets were negatively correlated with the amount of $P$. durangensis sawdust added. The bulk density of the pellets was negatively correlated with mechanical hardness and IRI. The calorific value of mixtures and the species $\times$ mixture interaction differed significantly between groups. Finally, the mean calorific value was highest (19.8 $\mathrm{MJ} \mathrm{kg}^{-1}$ ) in the $20: 80$ mixture. The calorific value was positively related to the addition of $P$. durangensis sawdust. 


\section{Improving the physical, mechanical and energetic} 2 properties of Quercus spp. wood pellets by adding 3 pine sawdust

Víctor Daniel Núñez-Retana1, Rigoberto Rosales-Serna², José Ángel Prieto-Ruiz ${ }^{3}$, Christian

Wehenkel $^{4}$, Artemio Carrillo-Parra ${ }^{4 *}$

7

8

${ }^{1}$ Maestría Institucional en Ciencias Agropecuarias y Forestales, Universidad Juárez del Estado

9 de Durango, Durango, Durango, México

${ }^{2}$ Campus Valle del Guadiana, Instituto Nacional de Investigaciones Forestales, Agrícolas y Pecuarias, Durango, Durango México

${ }^{3}$ Facultad de Ciencias Forestales, Universidad Juárez del Estado de Durango, Durango, Durango, México

${ }^{4}$ Instituto de Silvicultura e Industria de la Madera, Universidad Juárez del Estado de Durango, Durango, Durango, México

Corresponding Author:

18 Artemio Carrillo-Parra*

Boulevard del Guadiana No. 501, Durango, Durango, 34125, México.

Email address: acarrilloparra@ujed.mx

\section{Abstract}

Background. Biomass usage for energy purposes has emerged in response to global energy demands and environmental problems. The large amounts of by-products generated during logging are rarely utilized. In addition, some species (e.g. Quercus spp.) are considered less valuable and are left in the cutting areas. Production of pellets from this alternative source of biomass may be possible for power generation. Although the pellets may be of lower quality than other types of wood pellets, because of their physical and technological properties, the addition of different raw materials may improve the characteristics of the oak pellets.

Methods. Sawdust from the oak species Quercus sideroxyla, Q. rugosa, Q. laeta and Q. conzattii was mixed with sawdust from the pine Pinus durangensis in different ratios of oak to pine (100:0, 80:20, 60:40, 40:60 and 20:80). Physical and mechanical properties of the pellets were determined, and calorific value tests were carried out. For each variable, Kolmogorov-Smirnov normality and Kruskal-Wallis tests were performed and Pearson's correlation coefficients were determined (considering a significance level of $p<0.05$ ).

Results. The moisture content and fixed carbon content differed significantly $(p<0.05)$ between the groups of pellets (i.e. pellets made with different sawdust mixtures). The moisture content of 
40 addition of $P$. durangensis sawdust to the mixtures improved the bulk density of the pellets by

$4118 \%$. Significant differences $(p<0.05)$ in particle density were observed between species,

42 mixtures and for the species $\times$ mixture interaction. The particle density was highest in the 80:20

43 and 60:40 mixtures, with values ranging from 1,245 to 1,349 $\mathrm{kg} \mathrm{m}^{-3}$. Bulk density and particle

44 density of the pellets were positively correlated with the amount of $P$. durangensis sawdust

45 included. The mechanical hardness and impact resistance index (IRI) differed significantly $(p<$

$460.05)$ between groups. The addition of pine sawdust decreased the mechanical hardness of the

47 pellets, up to $24 \%$. The IRI was highest (138) in the $Q$. sideroxyla pellets (100:0). The

48 mechanical hardness and IRI of the pellets were negatively correlated with the amount of $P$.

49 durangensis sawdust added. The bulk density of the pellets was negatively correlated with

50 mechanical hardness and IRI. The calorific value of mixtures and the species $\times$ mixture

51 interaction differed significantly between groups. Finally, the mean calorific value was highest

$52\left(19.8 \mathrm{MJ} \mathrm{kg}^{-1}\right)$ in the 20:80 mixture. The calorific value was positively related to the addition of

53 P. durangensis sawdust.

54

55 Introduction

56

57

58

The increase in the world's population has created a greater demand for fossil fuels, which has

59

led to a scarcity of these materials and to unstable prices. According to the United Nations

59
60

Population Fund (UNFPA, 2019) the world's population was 7,000 million in 2010 and close to

60

7,715 million in 2019, representing an average annual rate of population change of $1.1 \%$ (for the

61

62 period 2010-2019). Plant biomass has become an important renewable resource and currently

63

64

65

66

67

68

69

70

71

72

73

74

75

76

77

78

79 covers approximately $15 \%$ of total energy consumption in the world (Holubcik, Jandacka \&

Durcansky, 2016).

Mexican temperate forests are dominated by pine-oak species (Galicia, Potvin \& Messier, 2015). Mexican pine-oak forests, which cover an area of 31.8 million hectares (FAO 1998), are commonly uneven-aged mixed forests (Wehenkel et al., 2011; Maciel-Nájera et al., 2020). Pinus wood production reached 5.0 million of $\mathrm{m}^{3}$ of roundwood in the last decade (SEMARNAT, 2016). Although Quercus spp. represent the second most important Mexican forest timber resource, covering an area of about 8.4 ha and yielding annual wood production of about 738,000 $\mathrm{m}^{3}$ of roundwood (SEMARNAT, 2016), these species remain almost underutilized (BárcenasPazos et al., 2008; Villela-Suárez et al., 2018).

Current methods of forest harvesting usually select pine species for harvesting, and logging activities also generate large amounts of by-products in the form of tree branches, tips, bark and sawdust. Logging thus changes the forest structure and species composition promoting the dominance of some species of low economic value, such as Mexican oaks in pine-oak forests (Moreno-Lopez, Alarcón-Herrera \& Martin-Dominguez, 2017). The dominance of oak trees interferes with natural restoration of pine populations under intensive wood production in

Peer) reviewing PDF | (2020:01:44846:2:0:NEW 22 Jul 2020) 
80

81

82

83

84

85

86

87

88

89

90

91

92

93

94

95

96

97

98

99

100

101

102

103

104

105

106

107

108

109

110

111

112

113

114

115

116

117

118

119

temperate forests. The presence of some Quercus species has been associated with negative effects such as shading (Puértolas, Benito \& Peñuelas, 2009), allelopathy, restrained seed germination and seedling radicle growth and inhibition of nitrifying bacteria, thus affecting the self-restoration of ponderosa pine and the herb understory (Li, Jia \& Li, 2007).

In Mexico, the disposal of solid timber by-products can create problems in forestlands and sawmills as it can lead to forest fires during periods of intense heat, generate dust in the air and block spaces in production installations (Fregoso-Madueño et al., 2017). Furthermore, pine wood is destined for the production of firewood, pulp, resin, edible seeds and other products such as furniture and boards (Sánchez, 2008) and therefore it should not be used to produce bioenergy. By-products and poorly formed stems and mature wood from oak trees could be used as an alternative source of material to produce bioenergy. Nevertheless, oak material is rarely transformed into pellets, because of technical problems due to the anatomical, physical, mechanical and drying characteristics of the timber (Miranda et al., 2011). The density of oak wood is considered medium to high (401 to $800 \mathrm{~kg} \mathrm{~m}^{-3}$ ) (Herrera-Fernández et al., 2017), which may lead to machining problems in sawmill systems during conversion (Zavala Zavala, 2003; Herrera-Fernández et al., 2017).

Pressing biomass into pellets has emerged as an efficient means of creating a renewable energy resource. However, not all species are easily pelletized, and the quality of the pellets is determined by the physical, mechanical, chemical and energetic properties. Mechanical properties such as strength and durability can be measured by compressive resistance testing, the tumbling can method, the Holmen Ligno tester and by impact resistance and water resistance methods (Kaliyan and Morey, 2009).

When the physical, mechanical and energetic properties of the pellets do not reach international standards, the quality can be improved by the use of mixtures of material to make the pellets. Indeed, researchers such as Kaliyan \& Morey (2009) and Harun \& Afzal (2016) recommend using mixtures of raw materials. Thus, Wilson (2010) mixed pine sawdust with white oak and red oak sawdust, thereby improving the durability of the pellets. Miranda et al. (2009) showed that pellets made from Quercus pyrenaica residues were suitable for energy applications. The same researcher used mixtures of Pyrenean oak and washed grape pomace to make pellets, which proved to have good physical and thermal properties (Miranda et al. 2011). Arranz et al. (2015) compared commercial pellets and an experimental type of Pyrenean oak pellet made in a semi-industrial pelletizer and found that the calorific values produced by some pellets were sufficient. These researchers therefore recommend taking specific actions to improve the pellet quality and optimize the operations in relation to collecting and handling the raw material. Similarly, Monedero, Portero \& Lapuerta (2015) recommended the addition of pine sawdust to poplar chips (Populus spp.) before pelletizing to improve the pellet quality and enable compliance with the established requirements of the standard EN 14961-2 (2012). 
120

121

122

123

124

125

126

127

128

129

130

131

132

133

134

135

136

137

138

139

140

141

142

143

144

145

146

147

148

149

150

151

152

153

154

155

156

157

158

159
The aim of this study was to improve the physical, mechanical and energetic properties of oak wood pellets (without bark) by mixing the oak sawdust with pine (P. durangensis) sawdust in different proportions before pelletizing the material.

\section{Materials \& Methods}

\section{Raw materials and experimental design}

Specimens of the oak species Quercus sideroxyla, Q. rugosa and Q. laeta were collected in the cutting areas in the Llano Blanco (SG.FO-08/-2014/91), El Nopal (SG.FO-08-2014/129), Chinatú (SG.FO-08-2014/52), El Pinito (SG.FO-08/2015/40) and El Tule y Portugal (SG.FO-082014/82) forest communities located in the municipality of Guadalupe y Calvo, state of Chihuahua, Mexico. Specimens of another oak species, Quercus conzattii, were collected from the Nicolás Romero forest area (SG/130.2.2.2/002203/17), and Pinus durangensis specimens were obtained from the El Regocijo forest community (SG/130.2.2.2/002243/11), both in the municipality of Durango, state of Durango, Mexico.

The material was collected by motor-manual harvesting, as follows: four logs were cut from pest- and disease-free specimens of each species, of diameter at breast height $(\mathrm{dbh}) \geq 25 \mathrm{~cm}$; the stem was required to be straight at least until the proposed height for cutting $(1.30 \mathrm{~m})$ due to the complexity for chipping.

\section{Preparation of biomass raw material and pellet manufacturing}

The logs were seasoned under laboratory conditions and debarked, cut and chipped using an Industrial Duty (SD4P25T61Y) machine. The sawdust was produced in a hammer mill (TFS 420) with a $3.15 \mathrm{~mm}$ mesh. The sawdust from each oak species was mixed with pine sawdust without bark in the following proportions (oak:pine): 100:0, 80:20, 60:40, 40:60 and 20:80. Ten $\mathrm{kg}$ of each mixture was prepared for pellet manufacturing. The sawdust was placed in rubber bags and mixed homogeneously.

The sawdust was conditioned by controlling the temperature of the boiler, by means of a digital controller, until 10\% humidity was reached. The sawdust was mechanically transported to the entrance of the ZLSP-R300 pelletizer to form the pellets (Fig. 1).

The pelletizer consists of a flat disc with channels $8 \mathrm{~mm}$ long and $6 \mathrm{~mm}$ wide and produces pellets at a rate of $400 \mathrm{~kg} \mathrm{~h}^{-1}$. Before the samples were pelleted, the temperature of the pelletizer was increased by processing pine sawdust only. The pelletizer was then constantly fed with the sawdust mixture until $8 \mathrm{~kg}$ of material per mixture was formed. The pellets were cooled by holding at room temperature for 24 hours (Fig. 2).

Peer] reviewing PDF | (2020:01:44846:2:0:NEW 22 Jul 2020) 
160

161

162

163

164

165

166

167

168

169

170

171

172

173

174

175

176

177

178

179

180

181

182

183

184

185

186

187

188

189

190

191

192

193

194

195

196

197

198

199

\section{Proximate analysis}

The cooled pellets were subjected to proximate analysis. The moisture content of the pellets was determined according to EN 18134-3 (2016). Samples were weighed on a $1 \mathrm{mg}$ precision weighing scale before and after drying in an oven for four hours at $105 \pm 2{ }^{\circ} \mathrm{C}$. The volatile matter was measured following standard EN 18123 (2016) in which the samples are heated at $900 \pm 10^{\circ} \mathrm{C}$ for seven minutes.

The ash content was measured according to standard EN 18122 (2016). Thus, the samples were initially weighed and placed in a muffle at $250{ }^{\circ} \mathrm{C}$ for one hour, and the temperature was then increased to $550{ }^{\circ} \mathrm{C}$ for two hours. The final weight was determined after cooling the samples in a desiccator. The amount of fixed carbon was calculated by subtracting the sum of moisture content, volatile matter and ash from 100\% (Carrillo-Parra et al., 2018).

\section{Physical properties}

Bulk density tests were carried out in triplicate in a $600 \mathrm{~mL}$ metal cylinder, according to the procedure outlined in standard EN-17828 (2016), in which the pellets were poured into the cylinder until it was full. A debris cone was then formed. The cylinder was then struck three times on a hard surface from a height of $150 \mathrm{~mm}$ to consolidate the pellets, and excess pellets were removed from the edge of the cylinder.

The pellet particle density $\left(\mathrm{kg} \mathrm{m}^{-3}\right)$ was estimated by measuring the weight and volume of 20 pellets.

\section{Mechanical properties}

The mechanical hardness was estimated by means of the drop test. The test consists of measuring the weight of each pellet before and after being dropped twice from a height of $1.85 \mathrm{~m}$ onto a concrete floor. Twenty repetitions were carried out per treatment. The impact resistance index (IRI) was then calculated as described by Richards et al $(1990)$, (IRI) $=(100 \times N) / n$, where $N$ is the number of drops, and $n$ is the total number of pieces after $N$ drops. The maximum IRI value is 200 . Small pieces weighing less than $5 \%$ of the total pellet weight were not considered.

\section{Energetic properties}

The pellet calorific value was calculated in a semi-automatic isoperibol calorimeter (LECO model AC600) in TruSpeed ${ }^{\circledR}$ mode and according to standard EN-14918 (2011). The sample for analysis was burned with a high oxygen pressure in a calorimetric pump under specified conditions. The tests were carried out in triplicate on an anhydrous basis. The calculation was performed automatically by the calorimeter. 
200

201

202

203

204

205

206

207

208

209

210

211

212

213

214

215

216

217

218

219

220

221

222

223

224

225

226

227

228

229

230

231

232

233

234

235

236

237

238

239

\section{Statistical analysis}

Kolmogorov-Smirnov normality tests and analysis of variance were performed for all the variables according the assumption of normality. Statistical analysis of the bulk density, particle density, calorific value, mechanical hardness and IRI data were performed according to a factorial design $(4 \times 5)$, for the factors species (4) and mixture (5). A Kruskal-Wallis test was applied for non-normally distributed variables. Pearson's correlation coefficients were calculated in order to evaluate the strength of association between the addition of Pinus durangensis sawdust and bulk density, mechanical hardness, IRI and calorific value, as well as between bulk density and mechanical hardness and IRI. All tests were performed considering a significance level of $p<0.05$ and were implemented in the statistical program RStudio ${ }^{\circ}$ version $3.2 .2 \mathrm{R}$ (Bolker, 2012).

\section{Results}

\section{Proximate analysis}

The moisture content differed significantly between species $\left(p=4.09 \times 10^{-5}\right)$, mixtures $(\mathrm{p}=1.14$ $\left.\times 10^{-7}\right)$ and for the species $\times$ mixture interaction $(p=0.001)$ (Table 1$)$. The moisture content was lowest in the pellets made from $Q$. sideroxyla $(2.0 \%)$, followed by those made from $Q$. conzattii $(2.3 \%)$ and Q. laeta $(2.7 \%)$ and Q. rugosa $(3.3 \%)$. The moisture content was highest in the pellets made from oak sawdust only (for all species). The pellets made from $Q$. sideroxyla mixed with pine in ratios of 80:20 and 60:40 had the lowest moisture contents, of $1.1 \%$ and $1.2 \%$, respectively. The moisture content of $P$. durangensis pellets $(4.8 \%)$ was higher than that of the pellets made from any of the mixtures.

The volatile matter content differed significantly between species $(p=0.001)$, but not between mixtures or for the species $\times$ mixture interaction $(p=0.07$ and 0.63 , respectively) (Table 1$)$. The mean values were highest in $Q$. sideroxyla and $Q$. laeta pellets ( $90.6 \%$ and $89.6 \%$, respectively), followed by $Q$. conzattii $(88.6 \%)$ and $Q$. rugosa $(87.3 \%)$ pellets. The values were in the range $81-91 \%$, and the volatile matter content of the pine pellets $(80.6 \%)$ was lower than in the pellets made from any of the mixtures.

There were no significant differences in ash content between species $(p=0.83)$, mixtures $(p=$ $0.86)$ or for the species $\times$ mixture interaction $(p=0.30)$ (Table 1). However, in all mixtures including $P$. durangensis, the ash content was below $0.7 \%$ (except $Q$. rugosa $100-0)$.

Fixed carbon differed significantly between species $(p=0.002)$ and for the species $\times$ mixture interaction $(p=0.001)$, while there were no significant differences for mixtures $(p=0.40)$ (Table 1). The mean fixed carbon content was highest in $Q$. rugosa $(8.8 \%)$ and $Q$. conzattii $(8.4 \%)$ followed by $Q$. laeta $(6.9 \%)$ and $Q$. sideroxyla $(6.6 \%)$ pellets. On the other hand, the fixed 
240 carbon content was highest in $Q$. rugosa pellets (100:0) $(11.8 \%)$ and lowest in the Q. laeta: $P$. 241 durangensis 20:80 mixture (5.6\%). The fixed carbon content of $P$. durangensis pellets (13.9\%) 242 was higher than in all mixtures.

243

244

245

246

247

248

249

250

251

252

253

254

255

256

257

258

259

260

261

262

263

264

265

266

267

268

269

270

271

272

273

274

275

276

277

278

279

\section{Physical properties}

Bulk density varied in the range $557-703 \mathrm{~kg} \mathrm{~m}^{-3}$. The bulk density did not vary significantly between species $(p=0.18)$ or for the species $\times$ mixture interaction $(p=0.99)$, but it did differ significantly between the mixtures $\left(p=1.04 \times 10^{-6}\right)(\mathrm{Fig} 3 \mathrm{~A})$. The value was highest in all 20:80 mixtures $\left(>646 \mathrm{~kg} \mathrm{~m}^{-3}\right)$ and lowest in the oak-only pellets $(100: 0)\left(<580 \mathrm{~kg} \mathrm{~m}^{-3}\right)$. The bulk density of the $P$. durangensis pellets was $647 \mathrm{~kg} \mathrm{~m}^{-3}$.

The particle density of pellets differed significantly between species $(p=0.01)$, mixtures $(p=$ $\left.1.08 \times 10^{-8}\right)$ and for the species $\times$ mixture interaction $\left(p=1.49 \times 10^{-11}\right)$ (Fig 3B). The mean particle density was highest in $Q$. laeta $\left(1,282 \mathrm{~kg} \mathrm{~m}^{-3}\right)$ followed by $Q$. sideroxyla $\left(1,257 \mathrm{~kg} \mathrm{~m}^{-3}\right)$ and $Q$. rugosa $\left(1,256 \mathrm{~kg} \mathrm{~m}^{-3}\right)$ and $Q$. conzattii $\left(1,246 \mathrm{~kg} \mathrm{~m}^{-3}\right)$ pellets. The particle density was highest in the 80:20 and 60:40 mixtures and varied in the range 1,245-1,349 $\mathrm{kg} \mathrm{m}^{-3}$. The particle density was highest in the 80:20 mixture of $Q$. laeta and $P$. durangensis. The particle density of the $P$. durangensis pellets was $1,227 \mathrm{~kg} \mathrm{~m}^{-3}$.

The pellet bulk density was positively correlated with the amount of $P$. durangensis sawdust added (Fig 3A). The bulk density of $Q$. laeta was most closely correlated $(r=0.82)$ with the amount of $P$. durangensis sawdust added, while that of $Q$. conzattii was least well correlated $(r=$ 0.71 ). On the other hand, except for $Q$. rugosa, the particle density was poorly correlated with the amount of $P$. durangensis sawdust added (Fig. 3B).

\section{Mechanical properties}

The mechanical hardness differed significantly between species $(p=0.01)$, mixtures $(p=7.32 \times$ $\left.10^{-7}\right)$ and for the species $\times$ mixture interaction $(p=0.001)$ (Fig. 4A). The mean percentage of retained mass was highest in $Q$. conzattii (69.1\%), followed by $Q$. laeta, $Q$. sideroxyla and $Q$. rugosa pellets: $63.7 \%, 61.4 \%$ and $61.0 \%$, respectively.

The mean percentage of retained mass was highest in all oak-only pellets (100:0) $(71 \%)$ and lowest in the 20:80 mixtures (54.3\%). The percentage of retained mass was highest in the $Q$. sideroxyla-only pellets (100:0) (78.2\%). The mean retained mass in the $P$. durangensis pellets was $58.4 \%$.

The IRI values also differed significantly between species $(p=0.01)$, mixtures $\left(p=3.64 \times 10^{-6}\right)$ and for the species $\times$ mixture interaction $(p=0.01)$ (Fig. 4B). The mean value was highest in $Q$. 
280

281

282

283

284

285

286

287

288

289

290

291

292

293

294

295

296

297

298

299

300

301

302

303

304

305

306

307

308

309

310

\section{Discussion}

\section{Proximate analysis}

313 The moisture content was below $10 \%$ for all species and mixtures, which are therefore classified 314 as M10 class according to EN 14961-2 (2012). Values for the oak-only pellets (100:0) were

315 higher than for all mixtures with pine sawdust. This is because oak wood has fewer empty voids 316 than pine wood, but large numbers of tyloses, which occlude the vessels and slow down the 317 drying process (Pérez-Olvera et al., 2015). In general, the moisture content was below the $6.5 \%$ 318 reported by Zamorano et al. (2011) for oak wood. It was lower than the range of $7.0-7.4 \%$ 319 reported by Miranda et al. (2011) for mixtures of Pyrenean oak wood and washed grape pomace. 
320 Moisture content is a physical property that can be controlled by means of natural or artificial

321

322

323

324

325

326

327

328

329

330

331

332

333

334

335

336

337

338

339

340

341

342

343

344

345

346

347

348

349

350

351

352

353

354

355

356

357

358

359

drying, and the values could therefore be optimized.

Volatile matter was lower in all oak-only pellets (100:0) than in the mixtures with pine sawdust. Values were similar to those reported by Arranz et al. (2015) for Pyrenean oak and pine forest residues ( 83.6 and $84.2 \%$, respectively) and higher than those reported by Miranda et al. (2011) (range $67.8-83.6 \%$ ). Values of volatile matter in pine were slightly lower than reported by Rollinson \& Williams (2016) for pine pellets (83.6\%) and by Qin, Keefe \& Daugaard (2018), who reported values in the range $81.2-82.6 \%$ for pellets from green beetle-killed and burned lodgepole pine. High volatile matter contents reveal important thermal properties. For example, pellet ignition is facilitated at low temperatures, which increases the efficiency during the combustion process (Torres-Ramos et al., 2015). However, a low volatile matter content will hinder ignition of biofuel (Vassilev, Vassileva \& Vassilev, 2015).

The ash content was generally lower in oak-only pellets than in the mixtures, except in the $Q$. rugosa (100:0) and Q. laeta (100:0) pellets. However, the ash contents of each species and mixtures were in accordance with the requirement specified by the standard EN- 14961-2 (2012) for non-industrial use class A1 $(\leq 0.7 \%)$. Quercus rugosa pellets were classified as A2 $(\leq 1.5 \%)$, while $P$. durangensis pellets were classified as A1, and the values were similar to those reported by Filbakk et al. (2011) for Pinus sylvestris (0.47\%).

The ash content was lower than the values reported by Zamorano et al. (2011) (3.3\%) and by Serrano et al. (2011) (3.1\%). Herrera-Fernández et al. (2017) mentioned that the ash content of the wood of some oak species reached $1.0 \%$. Variations in ash content can be attributed to several factors, including physiological adaptations of the species (Bárcenas-Pazos et al., 2008), collection method, drying and handling of logs (Zamorano et al., 2011) and the proportion of bark in the wood (Filbakk et al., 2011; Herrera-Fernández et al., 2017; Lerma-Arce, OliverVillanueva \& Segura-Orenga, 2017; Núñez-Retana et al., 2019). High ash contents cause slag formation, fouling and sintering (Vega-Nieva et al., 2016), negatively affecting the maintenance cost for both household and industrial users (Carrillo-Parra et al 2018).

Lower values for fixed carbon were obtained for pellets made from each of the four oak species (100:0) than that reported by Miranda et al. (2011) (12.65\%). The fixed carbon content of the pine pellets was similar to that reported by Poddar et al. (2014) (13.0\%), and it was below the range of $16.9-18.43 \%$ reported by Qin, Keefe \& Daugaard (2018). Fixed carbon is an important bioenergy parameter due to its relationship with potential energy of solid fuels, and high fixed carbon contents are associated with high calorific power and with low moisture content and volatile matter content (Chen, Peng \& Bi, 2015; Forero-Nuñez, Jochum \& Sierra, 2015).

\section{Physical properties}


360

361

362

363

364

365

366

367

368

369

370

371

372

373

374

375

376

377

378

379

380

381

382

383

384

385

386

387

388

389

390

391

392

393

394

395

396

397

398

399

The bulk density of the oak-only pellets (100-0) classified these as class BD550 ( $\left.\geq 550 \mathrm{~kg} \mathrm{~m}^{-3}\right)$ according to standard EN 14961-1 (2011). These pellets are therefore of lower quality than pellets including pine sawdust, and classified as BD600, but complied with the specifications established by EN 14961-2 (2012) ( $\left.\geq 600 \mathrm{~kg} \mathrm{~m}^{-3}\right)$ for wood pellets destined for non-industrial use. The $P$. durangensis pellets were also classified as suitable for non-industrial use.

The bulk density was higher in the oak pellets containing pine sawdust than in those made from oak sawdust only (Figure 3a). A similar response was observed by Monedero, Portero \& Lapuerta (2015). This can be explained by the higher bulk density of pine pellets relative to oak pellets.

Values of the bulk density of oak pellets were within the range reported for other species. For example, Miranda et al. (2015) reported bulk density values in the range $620-824 \mathrm{~kg} \mathrm{~m}^{-3}$ for pellets made from different raw materials, and they were higher than those established by Carrillo-Paniagua (2015) for residues of Hieronima alchorneoides and Eucalyptus spp (in the range $480-603 \mathrm{~kg} \mathrm{~m}^{-3}$ ).

Bulk density is an important factor due to its relationship with the space required for storage and transport of the pellets (Lehtikangas, 2001; Lerma-Arce, Oliver-Villanueva \& Segura-Orenga, 2017), as well as with the costs associated with these activities (Zamorano et al., 2011; GarciaMaraver et al., 2015). Higher bulk density corresponds to more energy per unit volume, thus indicating greater economic benefits (Rollinson \& Williams, 2016).

Particle density was lower in oak pellets (100:0) than in the oak-pine pellets, and the particle density was highest in the 80:20 mixtures. In a similar study carried out by Liu et al. (2016) with bamboo, the values were reduced by the addition of pine to the pellet mixture. In this study, the values increased in the (80:20) mixture and then decreased with the addition of $P$. durangensis sawdust until almost reaching the values obtained for the oak pellets (100:0). These researchers also reported values in the range $990-1,300 \mathrm{~kg} \mathrm{~m}^{-3}$. These differences can be attributed to the relatively lower density of bamboo $\left(540 \mathrm{~kg} \mathrm{~m}^{-3}\right)$ than of oak. However, the values obtained in the present study were higher than those reported by Monedero, Portero \& Lapuerta (2015) (range $\left.1,020-1,120 \mathrm{~kg} \mathrm{~m}^{-3}\right)$. The differences in density can be attributed to the fact that these researchers used poplar chips with particle density of $790 \mathrm{~kg} \mathrm{~m}^{-3}$ in the mixtures, and in the present study the particle density was highest in the oaks, in the range $1,118-1,271 \mathrm{~kg} \mathrm{~m}^{-3}$.

Similar values of pellet particle density were obtained by García et al. (2019) and Bergström et al. (2008), who reported values in the range 1,259 - 1,276 $\mathrm{kg} \mathrm{m}^{-3}$. Lehtikangas (2001) reported values in the range $1,146-1,350 \mathrm{~kg} \mathrm{~m}^{-3}$ for pellets made with different varieties of sawdust, logs and bark residues. Jamradloedluk \& Lertsatitthanakorn (2017) reported particle density values in

Peer] reviewing PDF | (2020:01:44846:2:0:NEW 22 Jul 2020) 
400 the range 1,30-to $1,800 \mathrm{~kg} \mathrm{~m}^{-3}$, which is much higher than the values reported here. However, the 401 differences may be due to the use of adhesives.

402

403

404

405

406

407

408

409

410

411

412

413

414

415

416

417

418

419

420

421

422

423

424

425

426

427

428

429

430

431

432

433

434

435

436

437

438

439

Particle density is an important parameter due to its influence on the apparent density and combustion behavior. Low density particles are needed in order to increase the burning period and energy production ( Qin, Keefe \& Daugaard, 2018). Particle density is also related to the moisture content of the raw material at the time of pelletizing, as at lower moisture content the friction increases through the plate in the matrix, which affects the movement of the particles and therefore, increases compression and density (García et al., 2019).

\section{Mechanical properties}

The durability, expressed as the percentage mass retained after dropping the pellets twice, was within the range $67-78 \%$ for all oak pellets (100:0), i.e. higher than the 51-74\% obtained for the pellets containing $P$. durangensis sawdust. The lower durability of the pellets containing pine sawdust can be attributed to the very low abrasion index reported for this material (12\%) (Gil et al., 2010).

Abedi, Cheng \& Dalai (2018) used the drop test to determine the mechanical durability of spruce and oat hull pellets with additives (lignin and proline) and without additives. For pellets without additives, the durability ranged from 55 to $61 \%$, and for pellets with additives, the values ranged from 60 to $90 \%$ (values similar to those reported here).

Carrillo-Parra et al. (2018) also observed significant differences $(p<0.05)$ in the retained mass in pellets made from three common tropical species. These researchers reported values of $49.4 \%$ for Havardia pallens, 61.7\% for Ebanopsis ebano, and 66.2\% for Acacia wrightii, respectively, without explaining the reason for these differences. These values were lower than reported here for oak species.

The impact resistance test, also known as the "drop resistance" or "shattering resistance" test (Kaliyan \& Morey, 2009), enables estimation of the degree of compaction of the pellets and the resistance to breakage. These are important factors, as pellets must be able to support the transport, charge, discharge, storage and combustion processes to which they are subjected and will affect the efficiency of a pellet burner stove or burners (Hu et al., 2015). The impact resistance also enables evaluation of the mechanical durability through the shock and / or friction of densified fuels (Temmerman et al., 2006), as well as the strength of inter-particle bonds (Forero-Nuñez, Jochum \& Sierra, 2015).

The values of the Impact Resistance Index (IRI) for the oak-only pellets (100:0) were in the range 113 - 138, and they were higher than in all mixtures, except for Q. rugosa 80:20 mixture

Peer) reviewing PDF | (2020:01:44846:2:0:NEW 22 Jul 2020) 
440

441

442

443

444

445

446

447

448

449

450

451

452

453

454

455

456

457

458

459

460

461

462

463

464

465

466

467

468

469

470

471

472

473

474

475

476

477

478

479

and for the of Q. laeta and Q. conzattii 60:40 and 40:60 mixtures. Overall, the IRI was lower in the pellets containing $P$. durangensis sawdust. This can be attributed to the increase in the amount of $P$. durangensis sawdust which probably produced a pressure change in the pelletization process. This contrasts with the observations made by Forero-Nuñez, Jochum \& Sierra (2015) for pellets made from cocoa shell mixtures and coal, in which the increase in cocoa shell mixture improved the impact resistance values, as with the use of fine particles $(<0.297$ $\mathrm{mm})$. On the other hand, similar IRI values were reported by Carrillo-Parra et al. (2018) for $A$. wrightii (116 and 160).

The inverse correlation between the bulk density of the pellets and mechanical properties can be attributed to the higher bulk density as the pellets harden. Thus, when high-density pellets are dropped twice onto a concrete floor they will not absorb the impact and will break, while lowerdensity pellets are more likely to absorb the impact and not break. However, future studies should analyze the variations in shape and size distributions in relation to durability of bulk materials, in specific, bulk modulus and elastic response of pellets, as these factors are relatively poorly understood (Wilson, 2010).

The variations in the findings of several laboratories regarding the mechanical properties of pellets may be due to the different methods used to determine the characteristics of the pellets or the different devices used to produce the pellets. Further studies should be carried out to compare different methods used to determine the mechanical properties.

\section{Energetic properties}

The calorific value of all pellets containing $P$. durangensis sawdust was slightly higher than that of the oak-only pellets. A similar pattern was described by Serrano et al. (2011) because of the higher calorific value of pine. The values were above the limit established by standard EN 14961-2 (2012) (16.5 -19.0 MJ kg-1), and the pellets can therefore be used for residential or industrial applications.

The calorific values obtained here were within the range reported for hardwoods (17.63 - 20.80 $\mathrm{MJ} \mathrm{kg}^{-1}$ ) by Telmo \& Lousada (2011). They are also similar to those reported by Monedero, Portero \& Lapuerta (2015) for poplar and pine mixtures, and by Miranda et al. (2011) for Pyrenean oak waste. However, the addition of this raw material to washed grape pomace decreased the calorific value of the pellets. On the other hand, Liu et al. (2016) reported a value of $18.2 \mathrm{MJ} \mathrm{kg}^{-1}$ for pine pellets, which is lower than the value reported here. The difference in values can be attributed to the physical and chemical properties, which can vary widely among different species (Miranda et al., 2015) and which are also influenced by the location, tree age, genetics and wood section in the canopy (Viana et al., 2018). 
480

481

482

483

484

485

486

487

488

489

490

491

492

493

494

495

496

497

498

499

500

501

502

503

504

505

506

507

508

509

510

511

512

513

514

515

516

517

518

519

520

521

522

\section{Conclusions}

The addition of $P$. durangensis sawdust to $Q$. sideroxyla, $Q$. rugosa, Q. laeta and $Q$. conzattii sawdust improved the bulk density and calorific value of the pellets made with the material. Making pellets with mixtures of oak and pine sawdust is therefore a potentially valuable alternative means of disposing of the by-products Quercus material generated by the forestry industry. On the other hand, the moisture and ash contents of the oak-pine pellets were in accordance with the limits established by standard EN 14961-2 $(\leq 10 \%$ and $\leq 0.7 \%$, respectively). Addition of the pine sawdust also improved the bulk density, with values reaching $703 \mathrm{~kg} \mathrm{~m}^{-3}$, so that the pellets met the requirements specified by EN $14961-2\left(\geq 600 \mathrm{~kg} \mathrm{~m}^{-3}\right)$. The mechanical hardness and IRI were lower in the pellets containing pine sawdust than in the other pellets. The calorific value of all mixtures increased with the addition of pine sawdust, reaching a maximum of $19.8 \mathrm{MJ} \mathrm{kg}^{-1}$. Mixing oak and pine sawdust produced pellets with acceptable values for important traits included in the international standards, which are used as quality parameters.

\section{Acknowledgements}

We thank Dr. Claudia Edith Bailón-Soto for assistance with the translation of this manuscript.

\section{References}

Abedi A, Cheng H, Dalai AK. 2018. Effects of Natural Additives on the Properties of Sawdust Fuel Pellets. Energy and Fuels 32:1863-1873. DOI: 10.1021/acs.energyfuels.7b03663.

Arranz JI, Miranda MT, Montero I, Sepúlveda FJ, Rojas CV. 2015. Characterization and combustion behaviour of commercial and experimental wood pellets in South West Europe. Fuel 142:199-207. DOI: 10.1016/j.fuel.2014.10.059.

Bárcenas-Pazos GM, Ríos-Villa R, Aguirre-Rivera JR, Juárez-Flores BI, Honorato-Salazar JA. 2008. Composición química y densidad básica relativa de la madera de dos especies arbustivas de encino blanco de la Sierra de Álvarez, SLP, México Chemical composition and relative basic density of two shrub white oak wood species from the Sierra de Álvarez. Madera y Bosques 14:81-94.

Bergström D, Israelsson S, Öhman M, Dahlqvist SA, Gref R, Boman C, Wästerlund I. 2008. Effects of raw material particle size distribution on the characteristics of Scots pine sawdust fuel pellets. Fuel Processing Technology 89:1324-1329. DOI: 10.1016/j.fuproc.2008.06.001.

Bolker B. 2012. R Development Core Team, bbmle: tool for general maximum likelihood estimation. R package version. vol. 1, no 5.2. Available at https://cran.rproject.org/web/packages/bbmle/index.html.

Carrillo-Paniagua T. 2015. Caracterización de pellets con fines energéticos elaborados a partir de residuos forestales. Universidad de Costa Rica.

Carrillo-Parra A, Ngangyo-Heya M, Colín-Urieta S, Foroughbakhch Pournavab R, RutiagaQuiñones JG, Correa-Méndez F. 2018. Physical, mechanical and energy characterization of wood pellets obtained from three common tropical species. PeerJ 6:16. DOI: 10.7717/peerj.5504.

Chen W-H, Peng J, Bi XT. 2015. A state-of-the-art review of biomass torrefaction, densification 
523

524

525

526

527

528

529

530

531

532

533

534

535

536

537

538

539

540

541

542

543

544

545

546

547

548

549

550

551

552

553

554

555

556

557

558

559

560

561

562

563

564

565

566

567

568

and applications. Renewable and Sustainable Energy Reviews 44:847-866. DOI:

10.1016/j.rser.2014.12.039.

FAO. 1998. State of forestry activity in Mexico. Available at http://www.fao.org/UNFAO/Bodies/NAFC/nafc98/NAFC4-E.HTM

Filbakk T, Jirjis R, Nurmi J, Høibø O. 2011. The effect of bark content on quality parameters of Scots pine (Pinus sylvestris L.) pellets. Biomass and Bioenergy 35:3342-3349. DOI: 10.1016/j.biombioe.2010.09.011.

Forero-Nuñez CA, Jochum J, Sierra FE. 2015. Effect of particle size and addition of cocoa pod husk on the properties of sawdust and coal pellets. Ingenieria E Investigacion 35:17-23. DOI: 10.15446/ing.investig.v35n1.46157.

Fregoso-Madueño JN, Goche-Télles JR, Rutiaga-Quiñones JG, González-Laredo RF, Bocanegra-Salazar M, Chávez-Simental JA. 2017. Alternative uses of sawmill industry waste. Revista Chapingo Serie Ciencias Forestales y del Ambiente 23:243-260. DOI: 10.5154/r.rchscfa.2016.06.040.

Galicia L, Potvin C, Messier C. 2015. Maintaning the high diversity of pine and oaks species in Mexican temperate forests: a new management approach combining functional zoning and ecosystem adaptability. Canadian Journal of Forest Research 45:1358-1368. DOI: 10.1139/cjfr-2014-0561.

Garcia-Maraver A, Rodriguez ML, Serrano-Bernardo F, Diaz LF, Zamorano M. 2015. Factors affecting the quality of pellets made from residual biomass of olive trees. Fuel Processing Technology 129:1-7. DOI: 10.1016/j.fuproc.2014.08.018.

García R, Gil M V., Rubiera F, Pevida C. 2019. Pelletization of wood and alternative residual biomass blends for producing industrial quality pellets. Fuel 251:739-753. DOI: 10.1016/j.fuel.2019.03.141.

Gil M V., Oulego P, Casal MD, Pevida C, Pis JJ, Rubiera F. 2010. Mechanical durability and combustion characteristics of pellets from biomass blends. Bioresource Technology 101:8859-8867. DOI: 10.1016/j.biortech.2010.06.062.

Harun NY, Afzal MT. 2016. Effect of Particle Size on Mechanical Properties of Pellets Made from Biomass Blends. Procedia Engineering 148:93-99. DOI: 10.1016/j.proeng.2016.06.445.

Herrera-Fernández AC, Carrillo-Parra A, Pedraza-Bucio FE, Correa-Méndez F, Herrera-Bucio R, López-Albarrán P, Rutiaga-Quiñones JG. 2017. Densidad, composición química y poder calorífico de la madera de tres especies de encino (Quercus candicans, $Q$. laurina y $Q$. rugosa). Ciencia Nicolaita \#72 91:399-404.

Holubcik M, Jandacka J, Durcansky P. 2016. Energy properties of wood pellets made from the unusual woody plants. AIP Conference Proceedings 1768. DOI: 10.1063/1.4963035.

Hu Q, Shao J, Yang H, Yao D, Wang X, Chen H. 2015. Effects of binders on the properties of bio-char pellets. Applied Energy 157:508-516. DOI: 10.1016/j.apenergy.2015.05.019.

Jamradloedluk J, Lertsatitthanakorn C. 2017. Influences of mixing ratios and binder types on properties of piomass pellets. Energy Procedia 138:1147-1152. DOI: 10.1016/j.egypro.2017.10.223.

Kaliyan N, Morey RV. 2009. Factors affecting strength and durability of densified biomass products. Biomass and Bioenergy 33:337-359. DOI: 10.1016/j.biombioe.2008.08.005.

Lehtikangas P. 2001. Quality properties of pelletised sawdust, logging residues and bark. Biomass and Bioenergy 20:351-360. DOI: 10.1016/S0961-9534(00)00092-1.

Lerma-Arce V, Oliver-Villanueva JV, Segura-Orenga G. 2017. Influence of raw material

Peer) reviewing PDF | (2020:01:44846:2:0:NEW 22 Jul 2020) 
569

570

571

572

573

574

575

576

577

578

579

580

581

582

583

584

585

586

587

588

589

590

591

592

593

594

595

596

597

598

599

600

601

602

603

604

605

606

607

608

609

610

611

612

613

614

composition of Mediterranean pinewood on pellet quality. Biomass and Bioenergy 99:9096. DOI: 10.1016/j.biombioe.2017.02.018.

Li G De, Jia LM, Li XW. 2007. Research advances in allelopathy of Quercus L. Forestry Studies in China 9:287-294. DOI: 10.1007/s11632-007-0046-7.

Liu Z, Mi B, Jiang Z, Fei B, Cai Z, Liu X. 2016. Improved bulk density of bamboo pellets as biomass for energy production. Renewable Energy 86:1-7. DOI:

10.1016/j.renene.2015.08.011.

Maciel-Nájera JF, Hernández-Velasco J, González-Elizondo MS, Hernández-Díaz JC, LópezSánchez CA, Antúnez P, Bailón-Soto CE, Wehenkel C. 2020. Unexpected spatial patterns of natural regeneration in typical uneven-aged mixed pine-oak forests in the Sierra Madre Occidental, Mexico. Global Ecology and Conservation. DOI: 10.1016/j.gecco.2020.e01074.

Miranda MT, Arranz JI, Rojas S, Montero I. 2009. Energetic characterization of densified residues from Pyrenean oak forest. Fuel 88:2106-2112. DOI: 10.1016/j.fuel.2009.05.015.

Miranda MT, Arranz JI, Román S, Rojas S, Montero I, López M, Cruz JA. 2011. Characterization of grape pomace and pyrenean oak pellets. Fuel Processing Technology 92:278-283. DOI: 10.1016/j.fuproc.2010.05.035.

Miranda T, Montero I, Sepúlveda FJ, Arranz JI, Rojas CV, Nogales S. 2015. A review of pellets from different sources. Materials 8:1413-1427. DOI: 10.3390/ma8041413.

Monedero E, Portero H, Lapuerta M. 2015. Pellet blends of poplar and pine sawdust: Effects of material composition, additive, moisture content and compression die on pellet quality. Fuel Processing Technology 132:15-23. DOI: 10.1016/j.fuproc.2014.12.013.

Moreno-Lopez M, Alarcón-Herrera MT, Martin-Dominguez IR. 2017. Feasibility of pelletizing forest residues in Northern Mexico. Waste and Biomass Valorization 8:923-932. DOI: 10.1007/s12649-016-9623-0.

Núñez-Retana VD, Wehenkel C, Vega-Nieva DJ, García-Quezada J, Carrillo-Parra A. 2019. The bioenergetic potential of four oak species from Northeastern Mexico. Forests 10:869. DOI: 10.3390/f10100869.

Pérez-Olvera C de la P, Dávalos-Sotelo R, Limón-Godina R, Quintanar-Isaías PA. 2015. Technological characteristics of the wood of two Quercus species from Durango, Mexico. Madera y Bosques 21:19-46.

Poddar S, Kamruzzaman M, Sujan SMA, Hossain M, Jamal MS, Gafur MA, Khanam M. 2014. Effect of compression pressure on lignocellulosic biomass pellet to improve fuel properties: Higher heating value. Fuel 131:43-48. DOI: 10.1016/j.fuel.2014.04.061.

Puértolas J, Benito LF, Peñuelas JL. 2009. Effects of nursery shading on seedling quality and post-planting performance in two Mediterranean species with contrasting shade tolerance. New Forests 38:295-308. DOI: 10.1007/s11056-009-9148-5.

Qin X, Keefe RF, Daugaard DE. 2018. Small landowner production of pellets from green, beetle-killed, and burned lodgepole pine. Energies 11:14. DOI: 10.3390/en1 1030648.

Richards SR. 1990. Physical testing of fuel briquettes. Fuel Processing Technology 25:89-100. DOI 10.1016/0378-3820(90)90098-D.

Rollinson AN, Williams O. 2016. Experiments on torrefied wood pellet: Study by gasification and characterization for waste biomass to energy applications. Royal Society Open Science 3:15. DOI: $10.1098 /$ rsos. 150578 .

Sánchez GA. 2008. Una visión actual de la diversidad y distribución de los pinos de México. Madera y Bosques 14:107-120.

SEMARNAT. 2016. Anuario estadístico de la producción forestal 2016. Available at

Peer] reviewing PDF | (2020:01:44846:2:0:NEW 22 Jul 2020) 
615

616

617

618

619

620

621

622

623

624

625

626

627

628

629

630

631

632

633

634

635

636

637

638

639

640

641

642

643

644

645

646

647

648

649

650

651

652

653

654

655

656

657

658

659

660

https://www.gob.mx/cms/uploads/attachment/file/282951/2016.pdf

Serrano C, Monedero E, Lapuerta M, Portero H. 2011. Effect of moisture content, particle size and pine addition on quality parameters of barley straw pellets. Fuel Processing Technology 92:699-706. DOI: 10.1016/j.fuproc.2010.11.031.

Spanish Association for Standarization (UNE). 2011. UNE-EN 14918: biocombustibles sólidos. Determinación del poder calorífico. Madrid: Spanish Association for Standarization (UNE).

Spanish Association for Standarization (UNE). 2011. UNE-EN 14961-1: biocombustibles sólidos. Especificaciones y clases de combustibles. Parte: 1: Requisitos generales. Madrid: Spanish Association for Standarization (UNE).

Spanish Association for Standarization (UNE). 2012. UNE-EN 14961-2: biocombustibles sólidos. Especificaciones y clases de combustibles. Parte 2: Pélets de madera para uso no industrial. Madrid: Spanish Association for Standarization (UNE).

Spanish Association for Standarization (UNE). 2016. UNE-EN 18134-3: biocombustibles sólidos. Determinación del contenido de humedad. Método de secado en estufa. Parte 3: Humedad de la muestra para análisis general. Madrid: Spanish Association for Standarization (UNE).

Spanish Association for Standarization (UNE). 2016. UNE-EN 18123: biocombustibles sólidos. Determinación del contenido en materia volátil. Madrid: Spanish Association for Standarization (UNE).

Spanish Association for Standarization (UNE). 2016. UNE-EN 18122: biocombustibles sólidos. Determinación del contenido de ceniza. Madrid: Spanish Association for Standarization (UNE).

Spanish Association for Standarization (UNE). 2016. UNE-EN 17828: biocombustibles sólidos. Determinación de la densidad a granel. Madrid: Spanish Association for Standarization (UNE).

Telmo C, Lousada J. 2011. Heating values of wood pellets from different species. Biomass and Bioenergy 35:2634-2639. DOI: 10.1016/j.biombioe.2011.02.043.

Temmerman M, Rabier F, Jensen PD, Hartmann H, Böhm T. 2006. Comparative study of durability test methods for pellets and briquettes. Biomass and Bioenergy 30:964-972. DOI: 10.1016/j.biombioe.2006.06.008.

Torres-Ramos R, Montero-Alpírez G, Beleño-Cabarcas MT, Toscano-Palomar L, Pérez-Pelayo LJ. 2015. Lignina obtenida de residuos agrícolas como biocombutible de tercera generación. Ciencia y Tecnología 15:151-164. DOI: 10.18682/cyt.v1i15.290.

Vassilev S V., Vassileva CG, Vassilev VS. 2015. Advantages and disadvantages of composition and properties of biomass in comparison with coal: An overview. Fuel 158:330-350. DOI: 10.1016/j.fuel.2015.05.050.

Vega-Nieva DJ, Ortiz-Torres L, Míguez-Tabares JL, Morán J. 2016. Measuring and predicting the slagging of woody and herbaceous Mediterranean biomass fuels on a domestic pellet boiler. Energy and Fuels 30:1085-1095. DOI: 10.1021/acs.energyfuels.5b02495.

Viana HF dos S, Rodrigues AM, Godina R, Matias JC de O, Nunes LJR. 2018. Evaluation of the physical, chemical and thermal properties of Portuguese maritime pine biomass. Sustainability 10:15. DOI: 10.3390/su10082877.

Villela-Suárez, JM, Aguirre-Calderón OA, Treviño-Garza EJ, Vargas-Larreta E. Availability of forest residues and potential for energy production in temperate firest in El Salto, Durango. Madera y Bosques 24:1-18. DOI: 10.21829/myb.2018.2431529.

Wehenkel C, Corral-Rivas JJ, Hernández-Díaz JC, Von Gadow K. 2011. Estimating balanced

Peer) reviewing PDF | (2020:01:44846:2:0:NEW 22 Jul 2020) 
661 structure areas in multi-species forests on the Sierra Madre Occidental, Mexico. Annals of 662 Forest Science 68:385-394. DOI: 10.1007/s13595-011-0027-9.

663 Wilson TO. 2010. Factors affecting wood pellet durability. Pennsylvania State University.

664 Zamorano M, Popov V, Rodríguez ML, García-Maraver A. 2011. A comparative study of quality 665 properties of pelletized agricultural and forestry lopping residues. Renewable Energy 666 36:3133-3140. DOI: 10.1016/j.renene.2011.03.020.

667 Zavala Zavala D. 2003. Efecto del sistema de aserrío tradicional en las características de la 668 madera de encinos. Madera y Bosques 9:29-39. DOI: 10.21829/myb.2003.921284. 
Figure 1

Schematic representation of the pelletizing process used in the Instituto de Silvicultura e Industria de la Madera of the Universidad Juárez del Estado de Durango (made by Víctor Daniel Núñez-Retana).

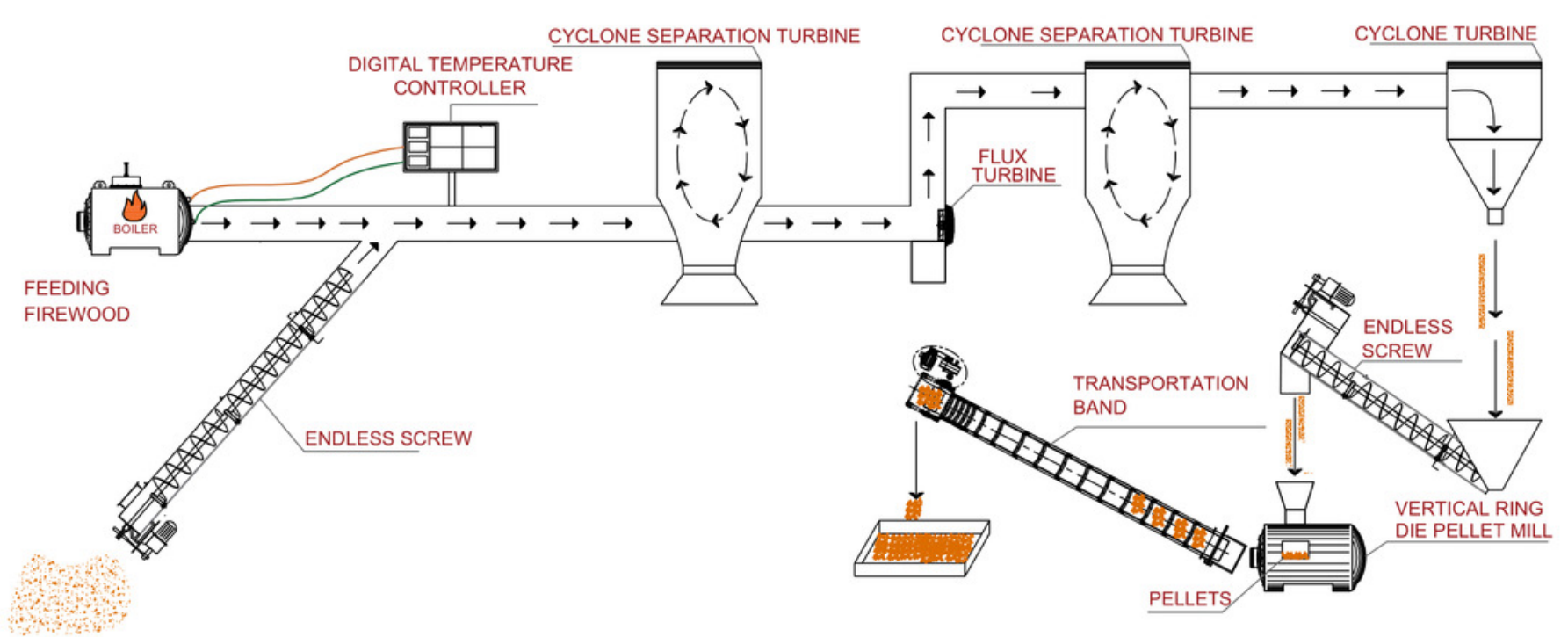


Figure 2

Pellets of different mixtures of oak-pine sawdust.

Horizontally (A-D) Mixes of 100:0. (E-H) Mixes of 80:20. (I-L) Mixes of 60:40. (M-P) Mixes of 40:60. (Q-T) Mixes of 20:80. Vertically (A-Q) Q. sideroxyla. (B-R) Q. rugosa. (C-S) Q. laeta. (DT) $Q$. conzattii species. 
A

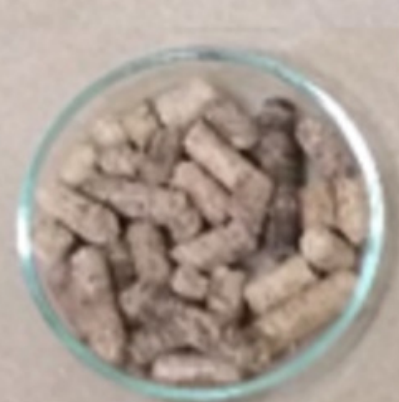

E

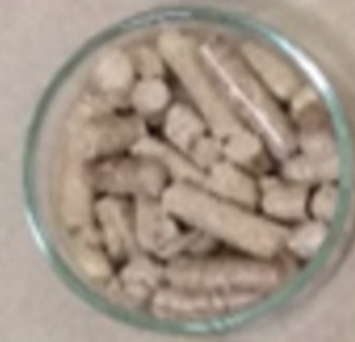

I

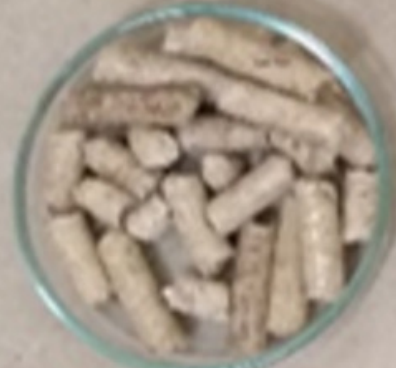

\section{M}

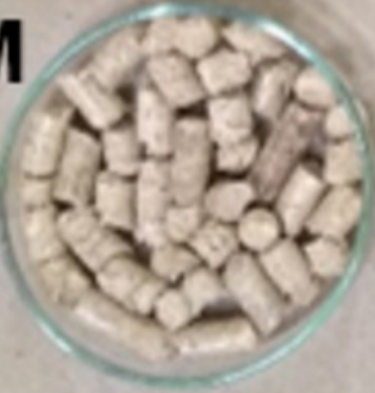

Q

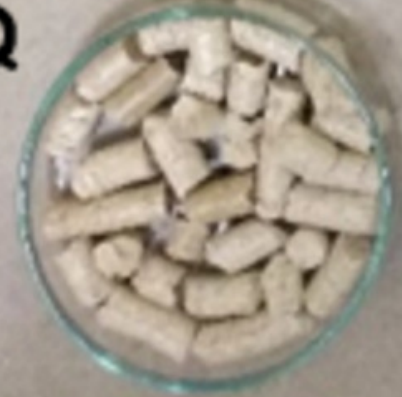

B
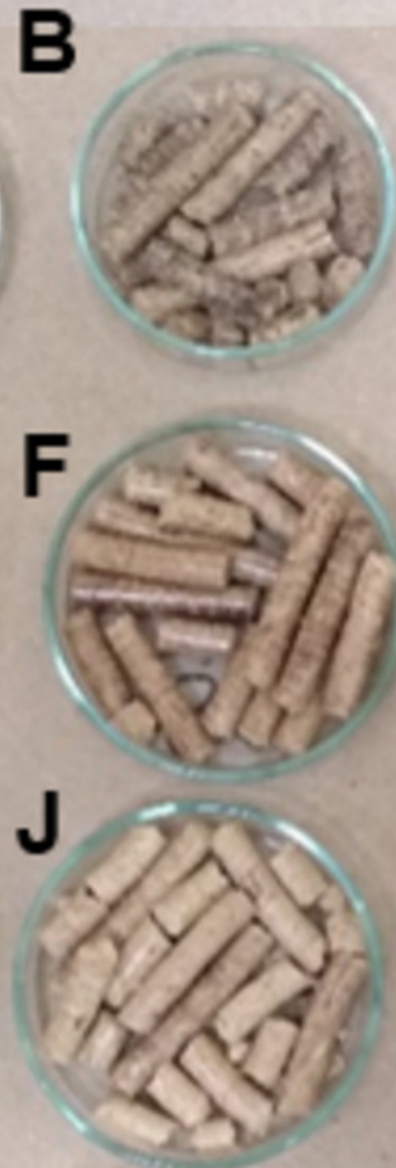

N
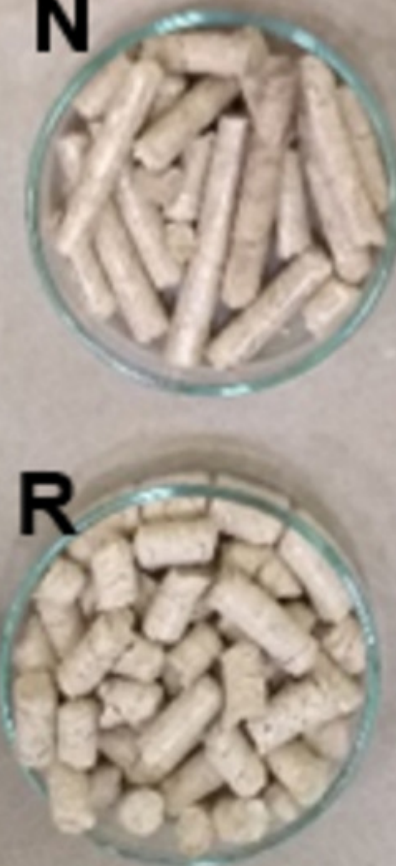

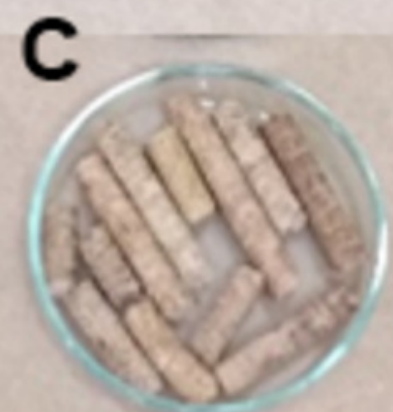

G

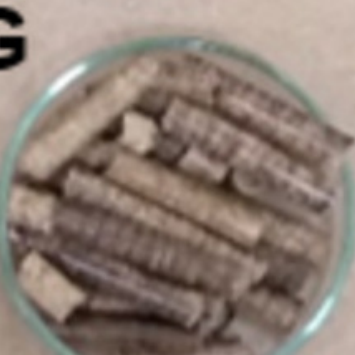

K

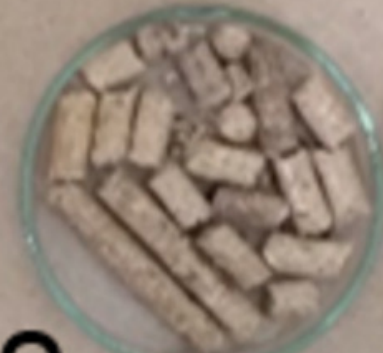

0
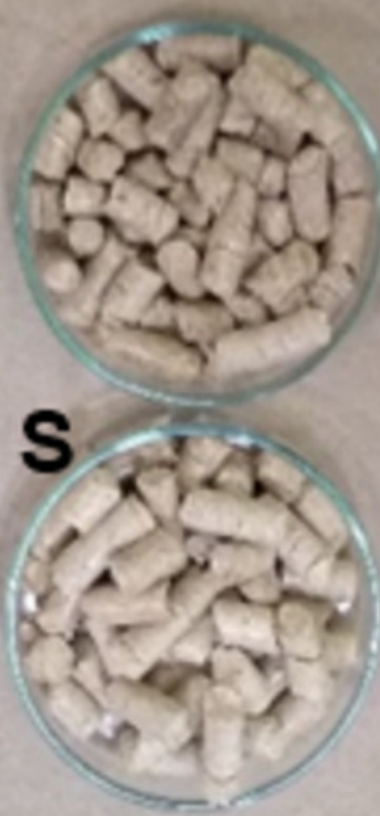

D

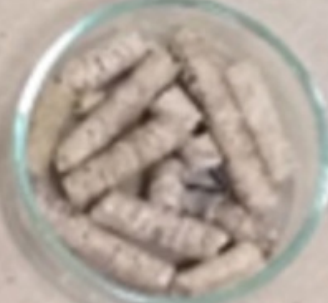

H

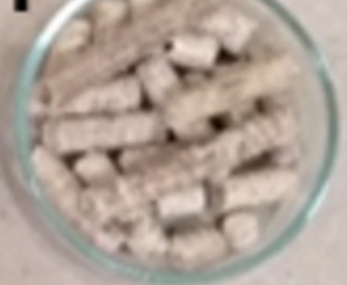

L

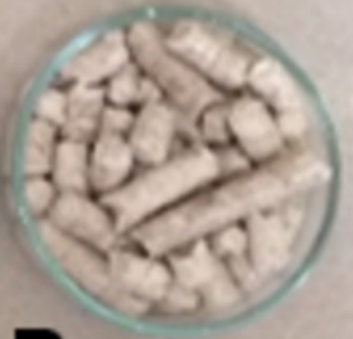

$\mathbf{P}$

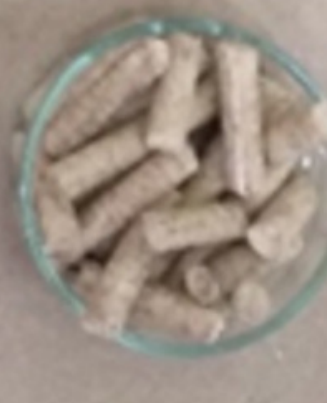

1

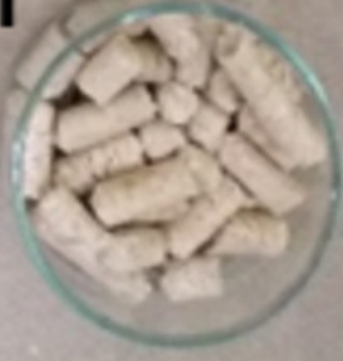


Figure 3

Addition of $P$. durangensis sawdust correlated with pellets bulk density $(A)$ and particle density (B) of four oak species.

A

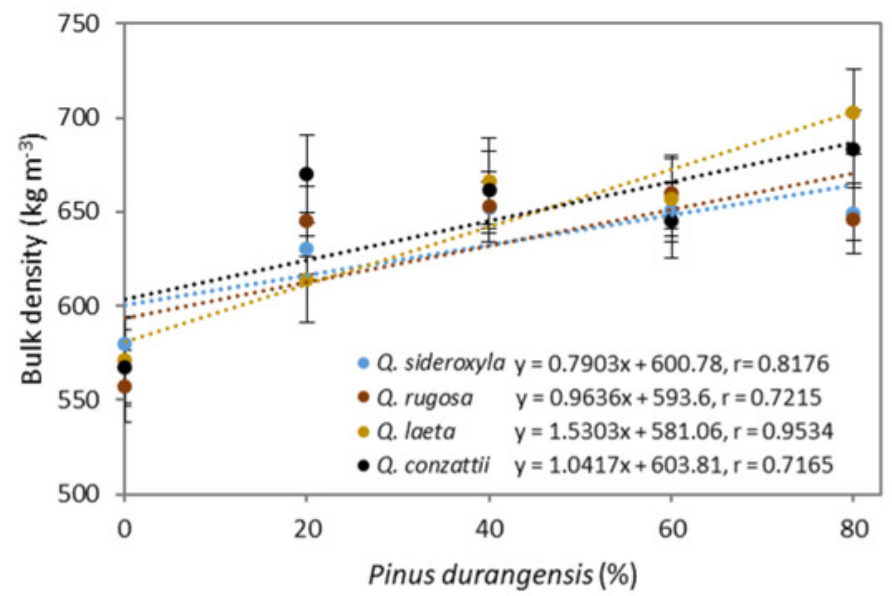

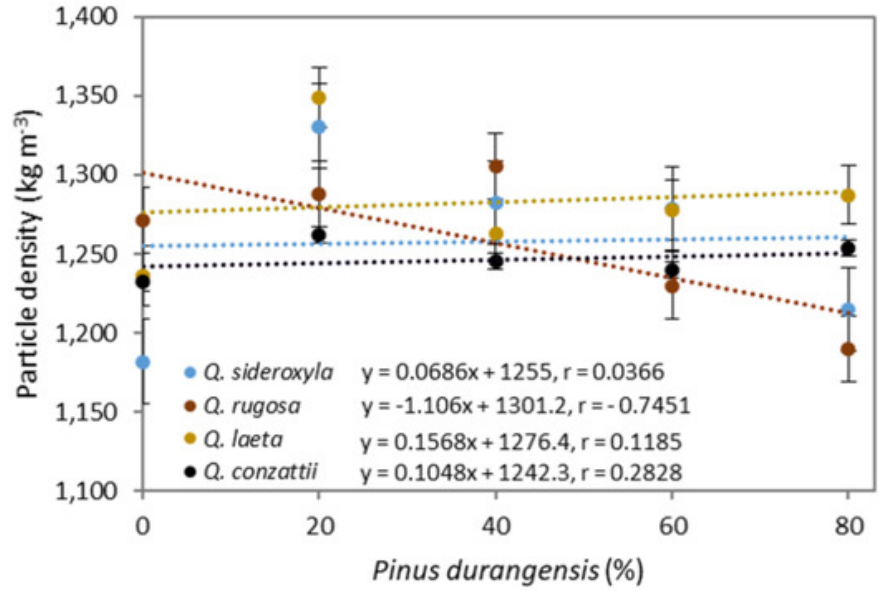


Figure 4

Addition of $P$. durangensis sawdust correlated with pellets mechanical hardness $(A)$ and Impact Resistance Index (B) of four oak species.

A

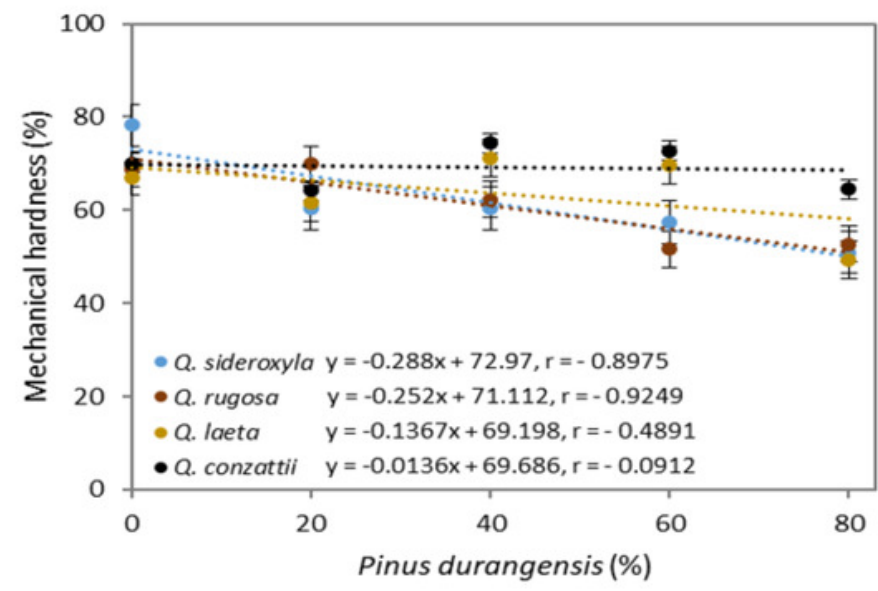

B

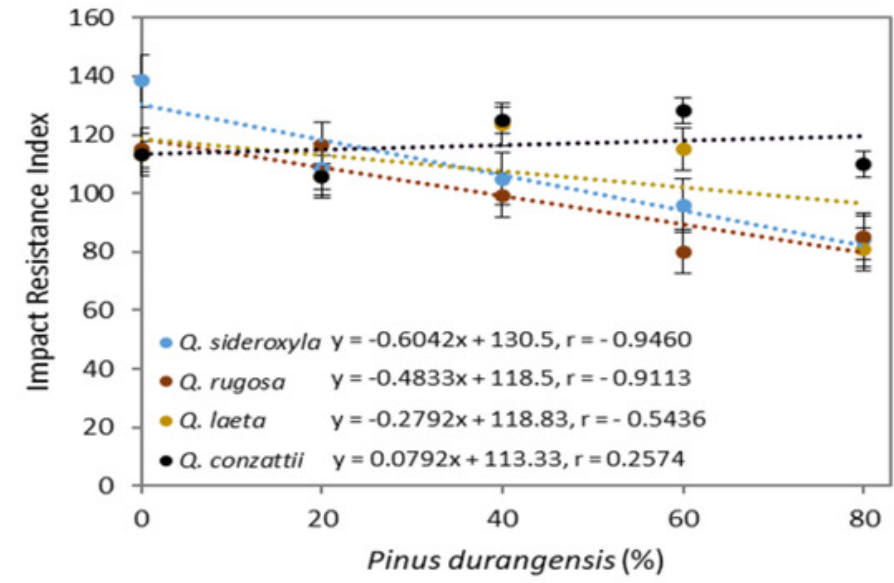


Figure 5

Pellets bulk density correlated with mechanical hardness (A) and Impact Resistance Index (B) of four oak species.
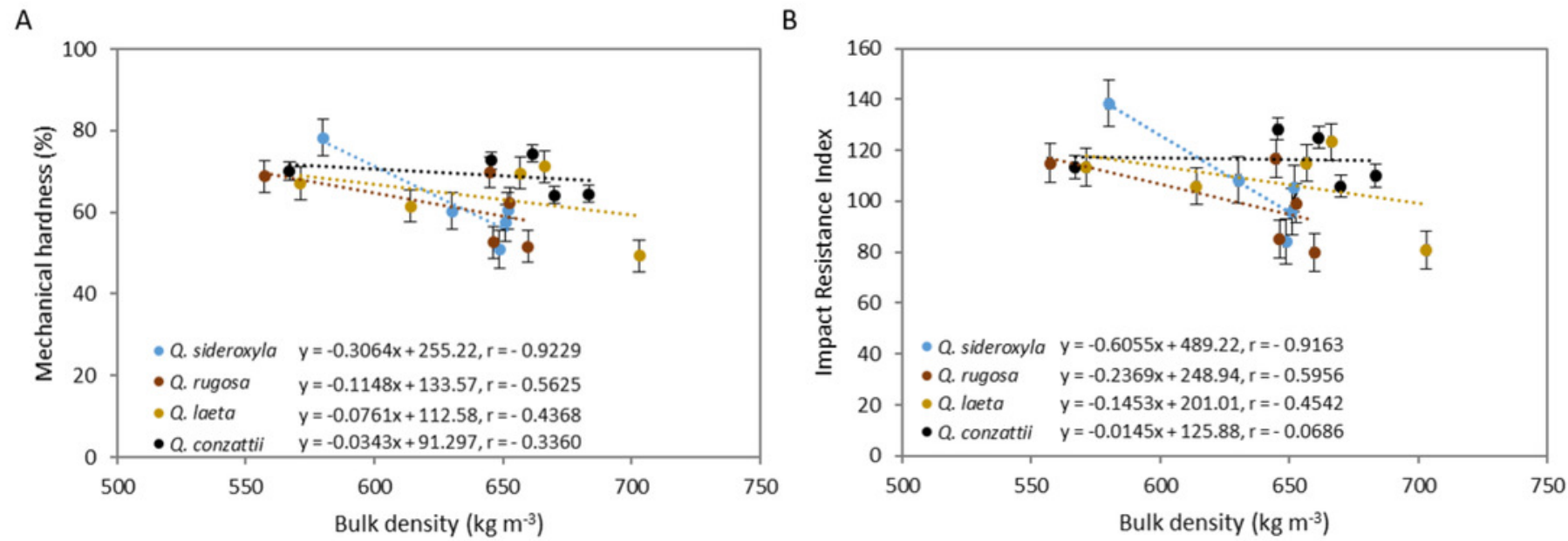
Figure 6

Pellets calorific value correlated with the addition of $P$. durangensis sawdust.

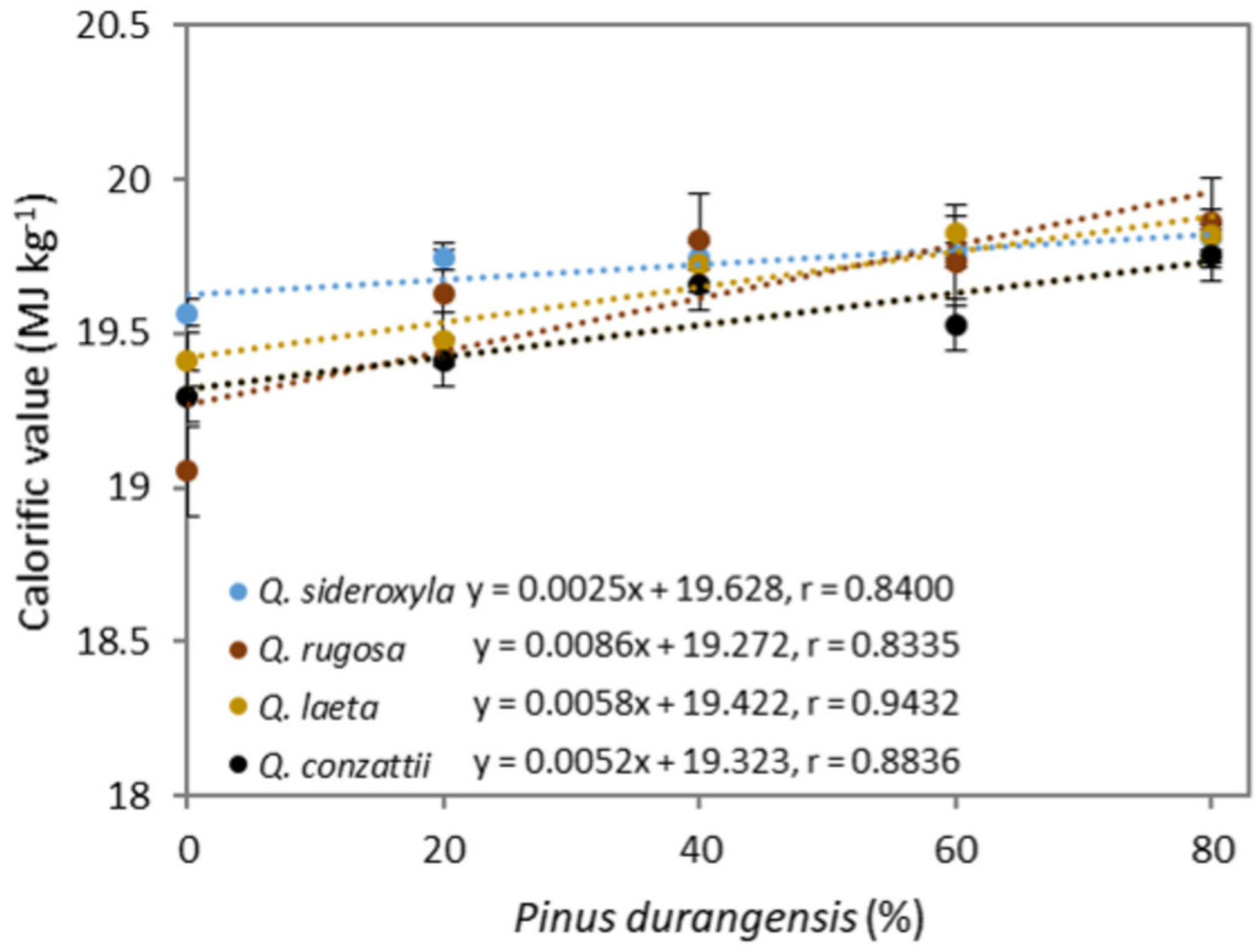




\section{Table $\mathbf{1}$ (on next page)}

Proximal analysis of pellets made from different mixtures of oak and $P$. durangensis sawdust.

MC: Moisture content; VM: Volatile matter; AC: Ash content; FC: Fixed carbon. Different letters correspond to significant statistical differences $p<0.05$. Capital letters corresponds to species and mixtures; lowercase letters correspond to species $\times$ mixture interaction. $*$ Pine values are added as a comparison parameter. 


\begin{tabular}{|c|c|c|c|c|}
\hline Factor & MC (\%) & MV (\%) & $\mathrm{AC}(\%)$ & FC $(\%)$ \\
\hline \multicolumn{5}{|l|}{ Species } \\
\hline Q. sideroxyla & $2.14 \mathrm{C}$ & $90.64 \mathrm{~A}$ & 0.54 & $6.65 \mathrm{~B}$ \\
\hline Q. rugosa & $3.22 \mathrm{~A}$ & $87.33 \mathrm{C}$ & 0.55 & $8.88 \mathrm{~A}$ \\
\hline Q. laeta & $2.90 \mathrm{~B}$ & $89.63 \mathrm{~A}$ & 0.51 & $6.93 \mathrm{~B}$ \\
\hline Q. conzattii & $2.35 \mathrm{~B}$ & $88.64 \mathrm{~B}$ & 0.57 & $8.44 \mathrm{~A}$ \\
\hline P. durangensis* & 4.80 & 80.68 & 0.53 & 13.91 \\
\hline \multicolumn{5}{|l|}{ Mixture } \\
\hline 100:0 & $3.78 \mathrm{~A}$ & 87.54 & 0.53 & 8.13 \\
\hline $80: 20$ & $2.09 \mathrm{~B}$ & 88.98 & 0.51 & 8.40 \\
\hline $60: 40$ & $2.24 \mathrm{~B}$ & 89.70 & 0.55 & 7.48 \\
\hline $40: 60$ & $2.35 \mathrm{~B}$ & 89.99 & 0.55 & 7.09 \\
\hline $20: 80$ & $2.78 \mathrm{~B}$ & 89.11 & 0.57 & 7.51 \\
\hline \multicolumn{5}{|c|}{ Q. sideroxyla - P. durangensis } \\
\hline 100:0 & $3.71 \mathrm{~b}$ & 89.76 & 0.36 & $6.15 \mathrm{k}$ \\
\hline $80: 20$ & $1.10 \mathrm{~m}$ & 91.34 & 0.47 & $7.07 \mathrm{j}$ \\
\hline $60: 40$ & 1.211 & 90.82 & 0.60 & $7.36 \mathrm{i}$ \\
\hline $40: 60$ & $2.11 \mathrm{j}$ & 91.08 & 0.65 & $6.13 \mathrm{k}$ \\
\hline $20: 80$ & $2.57 \mathrm{~h}$ & 90.23 & 0.62 & $6.56 \mathrm{k}$ \\
\hline \multicolumn{5}{|c|}{ Q. rugosa - P. durangensis } \\
\hline 100:0 & $3.36 \mathrm{e}$ & 84.00 & 0.74 & $11.88 \mathrm{a}$ \\
\hline $80: 20$ & $3.28 \mathrm{f}$ & 87.48 & 0.46 & $8.76 \mathrm{~d}$ \\
\hline $60: 40$ & $3.38 \mathrm{e}$ & 87.99 & 0.53 & $8.08 \mathrm{e}$ \\
\hline $40: 60$ & $3.43 \mathrm{~d}$ & 88.01 & 0.42 & $8.12 \mathrm{e}$ \\
\hline $20: 80$ & $2.65 \mathrm{~g}$ & 89.18 & 0.57 & $7.58 \mathrm{~g}$ \\
\hline \multicolumn{5}{|c|}{ Q. laeta - P. durangensis } \\
\hline 100:0 & $4.00 \mathrm{a}$ & 88.45 & 0.52 & $7.01 \mathrm{j}$ \\
\hline $80: 20$ & $2.64 \mathrm{~g}$ & 88.67 & 0.51 & $8.15 \mathrm{e}$ \\
\hline $60: 40$ & $2.66 \mathrm{~g}$ & 89.91 & 0.48 & $6.92 \mathrm{j}$ \\
\hline $40: 60$ & $1.72 \mathrm{k}$ & 90.83 & 0.55 & $6.89 \mathrm{j}$ \\
\hline $20: 80$ & $3.50 \mathrm{c}$ & 90.31 & 0.51 & 5.661 \\
\hline \multicolumn{5}{|c|}{ Q. conzattii - P. durangensis } \\
\hline 100:0 & $4.05 \mathrm{a}$ & 87.95 & 0.49 & $7.49 \mathrm{~h}$ \\
\hline $80: 20$ & $1.35 \mathrm{k}$ & 88.42 & 0.59 & $9.62 \mathrm{c}$ \\
\hline $60: 40$ & $1.73 \mathrm{k}$ & 90.07 & 0.60 & $7.58 \mathrm{f}$ \\
\hline 40:60 & $2.14 \mathrm{j}$ & 90.03 & 0.58 & $7.23 \mathrm{i}$ \\
\hline $20: 80$ & $2.42 \mathrm{i}$ & 86.72 & 0.58 & $10.26 \mathrm{~b}$ \\
\hline
\end{tabular}

